\author{
Dawid Junke \\ ORCID: 0000-0002-4894-994X \\ University of Wrocław
}

\title{
The showrunner as televisual auteur in promotional materials - a case study of posters for David Simon's television shows
}

\begin{abstract}
Within the rapidly evolving field of modern television, one of the issues which demand to be thoroughly analyzed is the matter of authorship. In the post-network era, the figure of a showrunner emerged as American television's answer to cinema's auteur. Since HBO's The Sopranos started the New Golden Age of TV, writer-producers such as Alan Ball and David Simon captivated the imagination of audiences and critics alike, with the last showrunner being famously compared to Charles Dickens, Leo Tolstoy and William Shakespeare. The aim of this article is to analyze onepage posters and ascertain how evident the concept of "showrunner as an auteur" is in said promotional materials. The article does not focus on the content of advertised shows, but rather tries to determine whether the artworks reflect the auteurist status of The Wire's showrunner, David Simon. The case study of posters for television shows run by David Simon demonstrates the rise of his supposed popularity and recognizbility. Operating on the assumption that poster credits are not only a part of contractually-bound transaction between the network and talent, but also function as one of the elements that attract prospective viewers, one can conclude that David Simon's auteurist brand, as recognized by HBO's publicity department, grew more prominent throughout the years.
\end{abstract}

Keywords: production studies, film marketing, authorship, auteur theory, film posters, David Simon, The Wire, The Deuce

\section{Introduction}

Television shows are among the most important - and most profitable cultural objects of the 21 st century's second decade. Their economic significance is evident and measurable, with just one player in the market, Netflix, reportedly generating 20.15 billion dollars in revenue in 2019 alone. When it comes to their artistic impact, influential cable dramas have been said to take up the torch 
of cultural relevance from great American novels. ${ }^{1}$ Careful and comprehensive study of the medium and surrounding discourses should therefore be considered to be of vital importance. On the rapidly evolving field of modern television there is a single issue that demands to be thoroughly analyzed, and it is the matter of authorship.

In the post-network era, ${ }^{2}$ the figure of a showrunner emerged as American television's answer to cinema's auteur. Since HBO's The Sopranos started the New Golden Age of TV, writer-producers such as David Chase, Vince Gilligan, Alan Ball, and David Simon captivated the imagination of audiences and critics alike, with the last showrunner being famously compared to Charles Dickens, Leo Tolstoy and William Shakespeare. ${ }^{3}$ The aforementioned surge of popularity and reverence for the auteur-like instance in an institution traditionally regarded as a writer's medium is the inspiration of my ongoing research project, of which this article is a part of.

The aim of this article is to analyze one-page posters and ascertain how evident the concept of "showrunner as an auteur" is in said promotional materials. I will not analyze the content of the advertised shows here, but rather try to determine whether the artworks reflect the auteurist status of The Wire's showrunner, David Simon. However, before I arrive at this point, a few of the key concepts to be used in the following article must be elaborated upon.

\section{Politique des auteurs and its critique}

\section{Production studies scholar Marcin Adamczak states that}

the mode of thinking about the film authorship and the social practice of actors [in the Latourian sense - D.J.] as disparate as film critics, distribution and marketing department's employees and viewers still seems to be governed by the 1960's theory known as politique des auteurs. ${ }^{4}$

In its classic form, politique des auteurs was developed by Francois Truffaut and other critics writing for Cahiers du Cinema in the 1950s and popularized

\footnotetext{
${ }^{1}$ B. Martin, Difficult Men: Behind the Scenes of a Creative Revolution: From "The Sopranos" and "The Wire" to "Mad Men" and "Breaking Bad", New York, NY 2013, p. 11.

2 "The post-network era" is defined by Amanda Lotz as a term that "acknowledges the break from a dominant network-era experience in which viewers lacked much control over when and where to view and chose among a limited selection of externally determined linear viewing options - in other words, programs available at a certain time on a certain channel. Such constraints are not part of the post-network television experience in which viewers now increasingly select what, when, and where to view from abundant options. The post-network distinction is not meant to suggest the end or irrelevance of networks - just the erosion of their control over how and when viewers watch particular programs" - A. Lotz, The Television Will be Revolutionized, New York, NY 2007, pp. 131-132.

${ }^{3}$ W. Mason, "The HBO auteur", The New York Times 17.03.2010, p. 26.

${ }^{4}$ M. Adamczak, "Współpraca w trakcie realizacji filmu a kwestia jego autorstwa", Tematy z Szewskiej 9, 2013, no 1, p. 61.
} 
in the United States by, inter alia, Andrew Sarris in the early 1960s. One of the conceptual pillars of the French New Wave, the theory sought for an authorial instance in cinema comparable to literature (the parallel developments in the field of literary theory - particularly the critique of "intentional fallacy" in New Criticism and the later proclamation of la mort de l'auteur - notwithstanding). They have found (or, rather, created) such an instance in film directors, to whom complete authority over a motion picture was ascribed. Adamczak then goes on to add that said theory has been criticized nearly from its inception - not only by the academics, but also by industry insiders. William Goldman famously assessed that no one in Hollywood believes in auteur theory. ${ }^{5}$ According to Goldman, the whole process of bringing a motion picture to life, from its inception to post-production, involves far too much decision-making processes to even "say who is responsible for what", ${ }^{6}$ let alone assign full authorship.

On film theory's ground auteur theory has been criticized from many perspectives: Thomas Schatz indicated that the style of the motion pictures produced within each and every one of the big studios in the classic Hollywood era was shaped in significant way by the executives, who were overseeing the studio's creative endeavors. According to Schatz, films made in that era "were the product not simply of individual human expression, but of a melding of institutional forces". ${ }^{7}$ Janet Steiger, together with David Bordwell and Kristin Thompson in their joint study entitled The Classical Film Style \& Mode of Production to 1960, have chronicled how the Hollywood mode of production prevented individuals from exercising absolute power over any production. ${ }^{8}$ Berys Gaut, in an article entitled Film Authorship and Collaboration, provided compelling arguments against single authorial instance in cinema and has put forward a proposition that actors, screenwriters, composers and other members of the crew should be included in a "multiple authorship theory". 9

\section{Showrunners as auteurs}

Authorship attribution is even more difficult in television, where the numbers of contributing cast and crew members in long-running series are far greater than

${ }^{5}$ W. Goldman, Adventures in the Screen Trade: A Personal View of Hollywood and Screenwriting, New York, NY 1989, p. 100.

${ }^{6}$ Ibid., p. 102.

7 T. Schatz, The Genius of the System: Hollywood Filmmaking in the Studio Era, Minneapolis 2010, p. 6.

${ }^{8}$ D. Bordwell, K. Thompson, J. Staiger, The Classical Hollywood Cinema. Film Style and Mode of Production to 1960, London 2005.

${ }^{9}$ B. Gaut, "Film authorship and collaboration", [in:] Film Theory and Philosophy, ed. R. Allen, M. Smith, Oxford 1997. 
in the film industry. One has to also take into account multiple executive producers and the authority of the network and production studio executives as well. Nevertheless, in recent years, a potential new authorial instance has emerged on the televisual landscape with the arrival of so-called showrunners. Dating back only to the early 1990s, the position in question still has not found a widely agreed-upon definition and therefore should be elaborated upon. According to Mikkel Jensen the term refers to "writer-producers who have both creative and managerial responsibilities".$^{10}$ The described position was humorously explained by Matthew Carnahan in an interview for the 2014 documentary on showrunners - in Carnahan's words "showrunning is like painting a painting, while writing a novel, while doing your taxes". 11

It is worth adding that the unclear status of a showrunner is muddled still further by the fact that it is an uncredited role. If one looks for the showrunner in the TV show's opening or closing credits, one has to look for them among the creators or executive producers. However, the holder of the "created by" credit does not always serve as a showrunner. By way of example, Dead Like Me (Showtime, 2003-2004) was created by Bryan Fuller, but he left the show during its first season due to creative differences with network executives and was replaced as a showrunner by John Masius.

Even though their position is not clearly defined and regulated by guild's rubrics, men and women who manage both creative and managerial responsibilities and supposedly tend to the show's unified style are portrayed as television's equivalent for auteur directors. On the grounds of television criticism, this thesis has been supported by books such as Difficult Men: Behind the Scenes of a Creative Revolution by Brett Martin and The Revolution Was Televised: The Cops, Crooks, Slingers, and Slayers Who Changed TV Drama Forever by Alan Sepinwall. The veneration of the most accomplished showrunners is also apparent in profiles published in respected periodicals such as The New Yorker ${ }^{12}$ and The New York Times. ${ }^{13}$

It should come as no surprise that immediately after the theory of showrunner as auteur gained mainstream recognition, it faced fierce scrutiny and was thoroughly critiqued. Craig Fehrman, writing for The New Republic, diagnosed this approach to a televisual creative process as "a showrunner fallacy" and accused its proponents of ignoring the invaluable contributions of other cast and crew members. ${ }^{14}$ Such allegations, as well-argumented as they may be, do not annul all

10 M. Jensen, “"From the mind of David Simon': A case for the showrunner approach”, Series - International Journal of TV Serial Narratives 3, 2017, no 2, p. 36.

11 Showrunners: The Art of Running a TV Show, dir. D. Doyle, Black Sheep Productions, Ireland 2014.

12 M. Singer, "The misfit", The New Yorker 14.02.2005, pp. 192-205.

13 W. Mason, op. cit.

14 C. Fehrman, "The showrunner fallacy", The New Republic 13.06.2013, https://newrepublic. com/article/113374/why-tv-critics-should-stop-focusing-showrunners (accessed: 7.10.2019). 
possible applications of auteur theory. However, in order to appropriately weigh the importance of the figure of auteur in television, one needs to focus primarily on what functions it performs within the industry. John Thornton Caldwell states that television authorship is "inherently protracted, collective, and contested" 15 but nevertheless

negotiated and collective authorship is an almost unavoidable and determining reality in contemporary film/television. Studio and network publicity departments still frequently hype supposed auteurs in marketing campaigns. Directors and showrunners are frequently anointed with the status. ${ }^{16}$

Following Caldwell's advice, I do not assume in advance that the showrunner has a deciding voice in all the most important creative decisions made on the show, instead I am interested in how he or she functions as a creative agency in the televisual discourse. One of the ways to further the research in that direction is to focus on the promotional materials of the given shows. That is why in this study I chose to focus on posters, which are deemed as one of the most important visual marketing devices within the film industry. ${ }^{17}$

\section{Posters and credits}

According to Finola Kerrigan, "the objective of producing a poster is to create 'want to see' in the mind of the consumer through communicating the essence of the film and highlighting the unique selling proposition such as cast, genre or other element, this must be combined with other considerations". ${ }^{18}$ There are numerous easily recognizable patterns within film and television poster design - a photograph of two people, a man and a woman, standing back-to-back, while posing on a white background will almost definitely promote a romantic comedy, while a close-up of an eye with dilated pupils or unexpected features almost invariably advertises a horror or sci-fi motion picture. ${ }^{19}$ Viewers instinctively recognize these similarities, as they are recurrent and meant to evoke a clear notion of what the public might expect from the advertised film or television show. The "want to see" can also be ignited by the star power of famous actors or directors, whose name hypothetically attracts viewers already familiar with their previous works. ${ }^{20}$

15 J.T. Caldwell, Production Culture: Industrial Reflexivity and Critical Practice in Film and Television, Durham, NC 2008, p. 201.

16 Ibid., p. 199.

${ }^{17}$ F. Kerrigan, Film Marketing, London 2009, p. 130.

18 Ibid., pp. 131-132.

${ }^{19}$ For an exhaustive list of poster trends, complete with illustrative collages, visit Christophe Curtois' blog — https://afficheschristophecourtois.blogspot.com (accessed: 7.12.2019).

${ }^{20}$ F. Kerrigan, op. cit., p. 133. 
While discussing the exposition of credits on posters, contractual obligations must be mentioned, as they significantly influence the advertising strategy and design of the artworks. Within the film industry it is traditionally assumed that actors - preferably high-ranking stars - are the main draw to a film, so their names are usually exempt from basic agreements of the non-actor guilds. ${ }^{21}$ Professionals employed in those occupations within the film industry which are less associated with star power - directors, DOPs, editors - negotiate the size of their credits in print advertisements relative to each other. According to Robert Marich

[c]ontract language may specify that one of several independent film companies that work on a film is entitled to billing "no smaller than any other possessory credit on a separate line". A possessory credit is an extra citation for a filmmaker stating "A Film By" or some similar phrasing that designates a creative signature on a film; the credit often appears above the title in ads that contain full billing. [...] Directors, producers, and writers often battle for such possessory credits in what goes beyond director or other guild basic agreements. ${ }^{22}$

Marich goes on to describe contracts stipulating that the lesser-known director of photography's name should be featured on advertising materials displayed within the metropolitan area of New York and Los Angeles. In such a case the presence of a professional's name on a poster is meant to further his or her career rather than to attract the audience (as the wider public is assumedly unfamiliar with the hypothetical DOP's name). Other contractual considerations include the exact position of a given individual's credit. In a not-uncommon situation of competition for more prestigious credit placement between two star actors "the solution can be to place both names in identical type and side by side. Because the left-hand position is considered better, the name on the right might be elevated slightly to attempt to achieve parity". ${ }^{23}$

The conditions in the case of posters for television and web series are somewhat different. Up until the mid-2000s, the vast majority of TV series would not include credits for actors or other talent - it was assumed that the marketing appeal of a television show lay predominantly in its genre. A typical one-sheet poster would usually include a title, the name of the network airing the show and its programming timeslot along with the tagline. ${ }^{24}$ When television's critical status began to rise with the advent of the New Golden Age and its successor in the form of the Peak TV period, advertising materials reflected this change to a certain extent. At the end of the second decade of the 21 st century, talent credits on TV posters are much more widespread than previously. Network and streaming platforms' executives have rightly assumed that newly arrived star-studded shows in the vein of Nic Pizzolato's

${ }^{21}$ R. Marich, Marketing to Moviegoers: A Handbook of Strategies and Tactics, Carbondale 2013, p. 18.

22 Ibid., p. 19.

${ }^{23}$ Ibid.

${ }^{24}$ See a poster for Desperate Housewives (showran by Marc Cherry, ABC 2004-2012) for example — http://www.impawards.com/tv/desperate_housewives.html (accessed: 8.12.2019). 
True Detective (during the three seasons aired at the time of writing this article, the credits included A-list Hollywood stars such as Matthew McConaughey, Woody Harrelson, Colin Farrell, Rachel McAdams, Vince Vaughn and Mahershala Ali) and David E. Kelley's Big Little Lies (which boasts a cast that includes Nicole Kidman, Reese Witherspoon, Meryl Streep, Zoë Kravitz and Laura Dern among others) can and should be marketed on equal terms with big budget Hollywood motion pictures. However, this tendency is by no means all-pervasive - numerous procedural shows are still advertised without any billings on posters. ${ }^{25}$

As mentioned above, credits on posters have several potential functions. They are seen as useful for the talent themselves, especially during the early stages of their career as they can increase name recognition among both industry insiders and the wide public. However, it is not only the debutants or second-tier talent, who seek to ensure best placing of credits on posters - as Marich writes,

billing can determine salary and standing on future films. Regarding talent's right to consultations, distributors often go to great lengths to appease talent concerns about advertising, hoping to cement a relationship so that talent will be inclined to make other films for the studio. ${ }^{26}$

The most important hypothetical effect for this article, however, is the assumed influence on the public. If a certain actor, director - or, in the case of television series - showrunner is deemed popular enough by the network executives and publicity strategists, then the credits are put on the poster to attract viewers familiar with the style of the artist in question. Analyzing the prominence and frequency of showrunners' credits on posters can thus help to verify the auteur status of a given showrunner through the lens of marketing, which — as pointed out by Corrigan ${ }^{27}$ — can be seen as the main area in which the auteur concept is clearly operationalized. The process of poster analysis will thus help to verify if the accolades and fan following are recognized by advertising specialists. All posters analyzed in this article are to be found in two trusted industry on-line archives: impawards.com and IMDb.

\section{David Simon - a showrunner superstar}

David Simon is arguably the most critically acclaimed active showrunner, a household name praised particularly for his contributions as the main creative force behind the legendary crime drama The Wire. The appreciation of Simon's oeuvre is also apparent in academia — numerous courses on The Wire have been

${ }^{25}$ For recent examples see: http://www.impawards.com/tv/bob_hearts_abishola.html, http://www. impawards.com/tv/evil.html, http://www.impawards.com/tv/witcher_ver2.html (accessed: 8.12.2019).

${ }^{26}$ R. Marich, op. cit., p. 19.

27 T. Corrigan, "The commerce of auteurism: A voice without authority", New German Critique 1990, no 49, pp. 48-49. 
taught on American campuses, ${ }^{28}$ the body of monographs and anthologies devoted to the show is also impressively wide. ${ }^{29}$

Mikkel Jensen, in his article entitled "'From the mind of David Simon': A case for the showrunner approach" makes a very compelling argument for treating the showrunner of The Wire as a televisual auteur. The Danish researcher notes that

\begin{abstract}
While HBO's motivation to grant Simon a large degree of creative freedom is rooted in economical rationales (self-promotion and profit), this creative freedom nonetheless gives Simon the chance he needs to tell stories that (with the exception of Generation Kill) all concentrate on the ills and appeals of the American city. And in that sense, it makes sense to see him as a strong showrunner who warrants a view of his oeuvre as a sustained statement, one that - taken as a whole - certainly does change both its area of focus and its overall mood or tone, but which consistently speaks to important issues about America's urban realities. ${ }^{30}$
\end{abstract}

In this article, however, I will not be looking closely into the content of the shows created by the former Baltimore Sun journalist. Instead, I will focus on Simon's assumed auteurist position - evident in academic and critical appreciation of his oeuvre - and seek its confirmation or rebuttal in printed promotional materials. A similarly oriented — though smaller in scope — task has been undertaken in Jensen's article quoted above, who has analyzed HBO's website devoted to the then-upcoming series, The Deuce. Jensen concludes that "the title of the webpage assigns ownership over the series to Pelecanos and Simon [...] HBO's promotional material, then, aims to elevate the television serial while emphasizing 'the author". ${ }^{31}$ While Jensen's analysis of the cable network's website is very accurate, this article will focus on arguably the most widely distributed form of advertisement - the promotional poster. The text will seek to answer the following questions: when did HBO start assigning attribution of shows produced by Simon to the showrunner on one-sheet posters and how apparent was that attribution?

Simon, a former journalist, cut his teeth as a TV writer under showrunner Tom Fontana on the series called Homicide: Life on the Streets (NBC 1993-1999). It is worth mentioning that said show was an adaptation of Simon's non-fiction book, Homicide: A Year on the Killing Streets (1991), but the future revered showrunner did not serve as the main creative agent. In fact, his involvement was quite limited - it "began in earnest in its fourth season (he did not receive a screen credit as story editor until the fifth season and did not become a fully-fledged producer

28 P. Cohen, "Teaching The Wire", 12.06.2012, https://theamericanscholar.org/teaching-the-wire/ (accessed: 8.12.2019).

${ }^{29}$ By way of example: S. Vint, The Wire, Detroit 2013; L. Williams, On "The Wire”, Durham 2014; "The Wire" and America's Dark Corners: Critical Essays, eds. A. Keeble, I. Stacy, Jefferson, NC 2015; "The Wire”: Urban Decay and American Television, ed. T. Potter, New York, NY 2009.

${ }^{30}$ M. Jensen, op. cit., p. 40.

31 Ibid., p. 32. 
until the sixth season)". ${ }^{32}$ When Simon finally became more involved, however, the experience of working with Fontana helped him to define his artistic priorities. In Simon's own words:

Homicide was the show on which I learned to write television [...] at the foot of Tom Fontana. Tom is a playwright and the guys working for him were either playwrights or television writers. They knew drama and what they were trying to do was to get to the human condition. I really respect the end product, but Tom's impulse was not journalistic. And mine kind of is. What I'm interested in is politics and sociology and economics. ${ }^{33}$

\section{Analysis of the credits on posters for David Simon's television shows}

Simon was given the opportunity to bring politics, sociology, and economics to the forefront in his next project, The Corner (HBO 2000). The mini-series, which found its home at HBO, where Simon would produce all of his upcoming shows, is based on a book entitled The Corner: A Year in the Life of an Inner-City Neighborhood (1997), another non-fiction account of Baltimore inner-city life, co-authored with Ed Burns, a former Baltimore homicide detective. The six-episode televisual adaptation premiered on HBO in 2000. As a miniseries, it was approached by the publicity department of its home cable network in a similar fashion to other limited series. The poster ${ }^{34}$ consists of the photographs of three actors playing the main characters - T.K. Carter, Khandi Alexander and Sean Nelson - on a yellow-tinted background, superimposed with a picture of the titular neighborhood. In the upper-left corner, the miniseries' tagline, written in skewed font, reads: "On the front lines of America's drug war, one family is living in the crossfire." The title is located in the middle-right part of the print, and directly under it one can find a format description: "A Six Hour Miniseries Based On A True Story". The bottom part of the poster highlights the show's airing timeslot and includes the HBO logo, but directly above it, the marketing team decided to put a short credit section, printed in classical Adrian Frutiger's Universe 39 typeface. The credits, shorter than in a usual theatrical poster - condensed to one line - include billings for producers, executive producer, director and the authors of the adapted book.

David Simon's name is therefore mentioned twice - as an executive producer and co-author of $A$ Year in the Life of an Inner-City Neighborhood. However important that billing might have been for Simon at the relatively early stage of

32 J.P. Vest, "The Wire", "Deadwood", "Homicide", and "NYPD Blue": Violence is Power, Santa Barbara 2010, p. 79.

33 The United States of Television: America in Primetime, season 1, episode 4, PBS/BBC 2011.

34 Poster for The Corner, designed by Schoolery Design, http://www.impawards.com/tv/corner. html (accessed: 7.12.2019). 
his TV career, it is by no means sizeable and the poster lacks a notable, additional credit in the form of above-the-title. ${ }^{35}$ A plausible explanation for the inclusion of those silver-screen-feature-like credits on a poster for The Corner is the fact that Simon's first show produced for HBO was a miniseries and thus was treated by the marketing department and poster designers as a "television event" — a limited series, close in its concise form to a silver screen motion picture and advertised with the use of a similar template. The "cinematic" quality of a miniseries should also not be overlooked, as it brings HBO's production close to a cultural form which traditionally enjoyed more respect and recognition. Credits at the bottom, printed in classic Universe 39 narrow lettering, help to create an aura of arthouse respectability, which the cable network was striving to create.

Such an interpretation seems to be supported by the fact that a billing for David Simon is nowhere to be found on posters for his next production at HBO, The Wire (HBO 2002-2008). Even though The Corner was met with favorable reviews, its creator did not gain enough recognition, it seems, to warrant a billing on the posters. The most popular prints ${ }^{36}$ for the first season show a silhouette of the main star, Dominic West, surrounded with pictures of him and other actors as well as props related to the titular theme of wiretapping and undercover police work. The whole composition is tinted in bright orange or dark blue, depending on the version of the poster. The other elements featured on the posters for the first season are: a tagline, located at the top ("Don't get played" in the orange version and "Listen carefully" in the blue one), series title in the lower half, and the scheduling information with the HBO logo at the bottom. Simon's name is thus not utilized in an attempt to attract viewers. The posters hint at the genre and atmosphere of the newly-premiering show, and the executives did not deem it necessary to use an actor's or other talent's star power. This approach did not change in posters promoting subsequent seasons - no billing was included, even though the actors were more easily recognizable in the photographs. ${ }^{37}$

The situation altered with the advent of Simon's next project - a miniseries called Generation Kill (HBO 2008). Another adaptation of a non-fiction book, it tells the story of a group of US Marine Corps soldiers who serve on the frontlines of the invasion of Iraq in 2003. Generation Kill premiered a mere four months after the last episode of The Wire was aired, and the cultural capital of the prestigious crime drama was exploited by the marketing department and poster designers. In fact, a mention of the showrunner was incorporated into the miniseries' tagline, as it reads: "From the creator of The Wire comes the new face of American war".

${ }^{35}$ Marich defines above the title credit as "a name appearing on the screen before the title of the movie and in print ads - under certain conditions - on top of the title, though in small print" —idem, op. cit., p. 19.

${ }^{36}$ Posters for the first season of The Wire: http://www.impawards.com/tv/wire.html, http:// www.impawards.com/tv/wire_ver2.html (accessed: 7.12.2019).

37 Posters for the consecutive seasons of The Wire: http://www.impawards.com/tv/wire_ver3. html (accessed: 10.12.2019). 
The mention of the creator's previous project is featured on almost all posters designed for the show, including the most widely distributed one, which consists of a monochromatic photograph of the main actor, Alexander Skarsgård, surrounded by logos and the tagline in white and red typeface. ${ }^{38}$ Two of the less-popular posters for Generation Kill even name David Simon as the creator in question, thereby providing the showrunner with his first above-the-title credit in the form of the line "From David Simon, the creator of The Wire" placed at the top of the poster. ${ }^{39}$ It seems that, as was the case with The Corner, the miniseries format of Generation Kill prompted HBO's marketing department to apply advertising strategies similar to those known from motion pictures intended for wide-screen release.

In his next big HBO production, Treme, Simon left Baltimore for New Orleans to show the city and its residents, many of whom were musicians, dealing with the aftermath of Hurricane Katrina. While Treme boasts an ensemble cast that includes John Goodman, Khandi Alexander, Wendell Pierce, and Rob Brown, the posters which promoted the show do not focus on the appearances of familiar actors. The designers opted instead to create an impression of a New Orleanian milieu and the resilient spirit of its inhabitants. One of the posters advertising the premiere of the then-upcoming series shows a smiling child, running in front of run-down houses in the Central City district, ${ }^{40}$ in the second one a silhouette of a trombone player is placed on a background of abstract paint splashes, which form the shape of Louisiana's state borders. ${ }^{41}$ Both of these artworks also feature an above-the-title credit: "A new series from the creators of The Wire" and "From the creator of The Wire", respectively. In the first example the authorship is implicitly extended to Eric Overmeyer - who collaborated with Simon on The Wire and shares a "created by" credit with him on Treme - and perhaps George Pelecanos as well as Nina Costroff Noble, both of whom worked as executive producers on both shows. The second poster, by contrast, mentions a singular creator, which indirectly refers to Simon, who was the sole recipient of the "created by" credit on The Wire. Furthermore, the posters for subsequent seasons of Treme do not feature any credits, limiting themselves instead to the imagery of New Orleanian neighborhoods and symbols of local traditions. ${ }^{42}$

The run of Treme ended after three seasons, in 2013. In his usual fashion, David Simon decided to follow a regular serial with a miniseries. Show Me a Hero (HBO

${ }^{38}$ Main poster for Generation Kill: https://www.imdb.com/title/tt0995832/mediaviewer/rm2053871360 (accessed: 10.12.2019).

39 Two posters for Generation Kill featuring Simon's above-the-title credit: https://www.imdb. com/title/tt0995832/mediaviewer/rm4137334273, https:/www.imdb.com/title/tt0995832/mediaviewer/rm3936007681 (accessed: 10.12.2019).

${ }^{40}$ First poster for Treme: https://www.imdb.com/title/tt1279972/mediaviewer/rm1074633729 (accessed: 10.12.2019).

${ }^{41}$ Second poster for Treme: https://www.imdb.com/title/tt1279972/mediaviewer/rm1309514 753 (accessed: 10.12.2019).

42 Posters for subsequent seasons of Treme: https://www.imdb.com/title/tt1279972/mediaviewer/ rm1326291969, https://www.imdb.com/title/tt1279972/mediaviewer/rm1108188161 (accessed: 10.12. 2019). 
2015), based on the non-fiction book of the same name by Lisa Belkin, focusing on the project of housing desegregation and starring Oscar Isaac as Nick Wasicsko, mayor of Yonkers, New York. The marketing campaign for Simon's then-newest production relied primarily on Isaac's star power. The actor's popularity was steadily growing, as he coupled his critically acclaimed performances in Inside Llewyn Davies (dir. J. \& E. Cohen, USA 2013) and Ex Machina (dir. A. Garland, USA 2015) with a casting for the then-soon-to-premiere Star Wars: The Force Awakens (dir. J.J. Abrams, USA 2015). Consequently, Isaac's appearance dominates all four posters advertising the limited series, and he receives a sizeable credit on all of them. ${ }^{43}$ Nevertheless, Simon's auteurist brand is also utilized by the marketing team - all of the posters feature a line alluding to his involvement in the project: "From the creator of The Wire and the director of Crash". The showrunner here shares attribution of authorship with Paul Haggis, the director of the Academy Award for Best Picture winning Crash (2004). Show Me a Hero is a rare example of a television production where the director's input is strongly underscored. ${ }^{44}$

David Simon's newest show at the moment of writing this article is The Deuce (HBO 2017-2019), a fictional — though thoroughly researched and historically adequate - account of the development of the porn industry in New York City during the 1970s and 1980s. The first season of the show was promoted by an artwork stylized as a grindhouse poster, showing a sepia-tinted gallery of characters and porn-industry attributes standing out clearly against a white background. ${ }^{45}$ Even though, as was the case with Show Me a Hero, The Deuce stars an A-list Hollywood star - James Franco - the poster for Simon's newest show does not rely only on the actor's star power. Admittedly, Franco is still the most prominent figure on the artwork, but the only credit is that for Simon and his frequent collaborator, as the above-the-title reads: "From executive producers David Simon and George Pelecanos of The Wire". What is more important, is that the credit is also placed on posters for the second and third season of The Deuce, ${ }^{46}$ while Simon's previous shows' advertising strategies abandoned the "auteurist framing" after they premiered and hypothetically gained enough recognizability to be promoted on their own merits.

43 Posters for ShowMeaHero:https://www.imdb.com/title/tt2492296/mediaviewer/rm2582702336; https://www.behance.net/gallery/28584309/Show-Me-A-Hero-HBO (accessed: 10.12.2019).

44 The reason, besides Haggis' reputation, is feasibly that he directed all six episodes of the miniseries. It is a rare feat on American television, and Haggis undertook this task due to his reverence for Simon's work. See: A. Sepinwall, “'Show Me a Hero' director Paul Haggis on Oscars, TV, and his love of "The Wire", https:/uproxx.com/sepinwall/show-me-a-hero-director-paul-haggis-on-oscarstv-and-his-love-of-the-wire/ (accessed: 12.12.2019).

${ }^{45}$ Poster for the first season of The Deuce, designed by Canyon Design Group: http://www. impawards.com/tv/deuce.html (accessed: 12.12.2019).

46 Posters for the second and third season of The Deuce, designed by Canyon Design Group and BLT Communications, LLC respectively, http://www.impawards.com/tv/deuce_ver3.html, http:// www.impawards.com/tv/deuce_ver4.html (accessed: 12.12.2019). 


\section{Conclusion}

The case study of posters for television shows produced by David Simon demonstrates a rise of his supposed popularity and recognizability. Operating on the assumption that poster credits are not only a part of a contractually-bound transaction between the network and talent, but also function as one of the elements that attract prospective viewers, one can conclude that David Simon's auteurist brand, as recognized by HBO's publicity department, grew more prominent over the years. Simon did not receive an above-the-title credit on The Wire, in spite of the fact that he was previously engaged in the production of Homicide: Life on the Streets. Even after The Wire proved tremendously successful with critics and audiences alike, Simon's engagement in Treme was merely indirectly implied, as the posters advertised the premiere of a show "from the creator of The Wire". One should also stress that the artwork for the second and third seasons of the New Orleans-based serial featured no credits at all, focusing on its assumedly established marque. It was not before the most recent Simonian show premiered, when his brand as author was more extensively recognized by advertising strategists, although on posters promoting The Deuce he shared the credit with George Pelecanos.

One should also add that the above-described tendency is less apparent in the case of Simonian miniseries. Simon's engagement was recognized in the form of a credit already on a poster for The Corner, his first limited series produced for HBO. Artworks designed to promote Generation Kill and Show Me a Hero have also had an above-the-title mention, even though not all of them explicitly named Simon as the "creator of The Wire" in question. This earlier appearance of an auteurist marketing strategy on posters designed for a miniseries could be explained by the fact that limited series' advertising campaigns have traditionally been modeled on feature films designed for wide theater release rather than on regular multi-season serials. ${ }^{47}$ Their transient nature and compact airing schedule resembles a traditionally short box-office window. The invocation of the creator's name on the poster may therefore help to secure ratings success, in addition to reinforcing HBO's elitist status as "not TV".

Even though posters are - quite literally - the most visible and noticeable part of a television show's marketing campaign, they are by no means the only essential one. Further research into a showrunner's auteur status in modern television should therefore seek evidence in other promotional materials - press-releases, teasers, trailers, on-line ads and more. Such an approach, combined with analyzes of interviews, social-media statuses and other elements of discourse cre-

${ }^{47}$ Compare, by way of example, posters for other HBO miniseries - Band of Brothers (2001), Angels in America (2003) and Mildred Pierce (2011): http://www.impawards.com/tv/band_of_brothers. $\mathrm{html}$, http://www.impawards.com/tv/angels_in_america.html, http://www.impawards.com/tv/mildred pierce.html (accessed: 12.12.2019). 
ated by the showrunners themselves would help to create a clearer account of the ways in which politique des auteurs is utilized in post-network era television.

\section{Showrunner jako telewizyjny auteur w materiałach promocyjnych — studium przypadku plakatów do seriali telewizyjnych Davida Simona}

\section{Abstrakt}

Jednym z tematów domagających się szczególnej uwagi w obrębie dynamicznie rozwijającego się pola współczesnej telewizji jest kwestia autorstwa. W erze post-network figura showrunnera odgrywa w amerykańskiej telewizji rolę analogiczną do kinowego autora. Odkąd Rodzina Soprano (HBO) rozpoczęła Nową Złotą Erę Telewizji, tak zwani hyphenates (czyli osoby łączące funkcje producenta i scenarzysty), tacy jak Alan Ball i David Simon, zawładnęli wyobraźnią zarówno widzów, jak i krytyków — drugi z wymienionych showrunnerów był porównywany między innymi do Charlesa Dickensa, Lwa Tołstoja czy Williama Shakespeare'a.

Celem niniejszego artykułu jest analiza plakatów promujących seriale telewizyjne i wykazanie, na ile zaznacza się w nich idea ,showrunnera jako auteura”. Tekst nie skupia się na analizie zawartości reklamowanych seriali, zamiast tego stara się ocenić, czy badane prace plastyczne potwierdzają status showrunnera Prawa ulicy, Davida Simona, jako auteura. Studium przypadku plakatów do seriali telewizyjnych, których showrunnerem był David Simon, wskazuje, że jego hipotetyczna popularność i rozpoznawalność rosła z czasem. Zakładając, iż imienne wzmianki na plakatach są nie tylko częścią transakcji pomiędzy stacją telewizyjną a jej pracownikami, lecz funkcjonują także jako jeden z elementów mających przyciągnąć uwagę potencjalnych widzów, można uznać, że marka Davida Simona jako auteura — w oczach działu marketingowego HBO — wyraźnie zwiększyła swoją wartość w czasie jego dotychczasowej kariery.

Słowa-klucze: studia produkcyjne, marketing filmowy, autorstwo, teoria autora, plakaty filmowe, David Simon, Prawo ulicy, Kroniki Times Square

\section{Bibliography}

Adamczak M., "Współpraca w trakcie realizacji filmu a kwestia jego autorstwa”, Tematy z Szewskiej 9, 2013, no 1, pp. 56-75.

Bordwell D., Thompson K., Staiger J., The Classical Hollywood Cinema. Film Style and Mode of Production to 1960, London 2005.

Caldwell J.T., Production Culture: Industrial Reflexivity and Critical Practice in Film and Television, Durham, NC 2008.

Cohen P.M., "Teaching The Wire", 12.06.2012, https://theamericanscholar.org/teaching-the-wire/.

Corrigan T., "The commerce of auteurism: A voice without authority", New German Critique 1990, no 49 , pp. 43-57. 
Fehrman C., "The showrunner fallacy”, The New Republic 13.06.2013, https://newrepublic.com/ article/113374/why-tv-critics-should-stop-focusing-showrunners.

Gaut B., "Film authorship and collaboration", [in:] Film Theory and Philosophy, ed. R. Allen, M. Smith, Oxford 1997, pp. 149-172.

Goldman W., Adventures in the Screen Trade: A Personal View of Hollywood and Screenwriting, New York, NY 1989.

Jensen M., "From the mind of David Simon': A case for the showrunner approach", Series - International Journal of TV Serial Narratives 3, 2017, no 2, pp. 31-42.

Kerrigan F., Film Marketing, London 2009.

Lotz A., The Television Will be Revolutionized, New York, NY 2007.

Marich R., Marketing to Moviegoers: A Handbook of Strategies and Tactics, Carbondale 2013.

Martin B., Difficult Men: Behind the Scenes of a Creative Revolution: From "The Sopranos" and "The Wire" to "Mad Men" and "Breaking Bad", New York, NY 2013.

Mason W., "The HBO auteur", The New York Times 17.03.2010, p. 26.

Schatz T., The Genius of the System: Hollywood Filmmaking in the Studio Era, Minneapolis 2010.

Sepinwall A., "'Show Me a Hero' director Paul Haggis on Oscars, TV, and his love of 'The Wire", https://uproxx.com/sepinwall/show-me-a-hero-director-paul-haggis-on-oscars-tv-and-his-love-of-the-wire/.

Singer M., "The misfit", The New Yorker 14.02.2005, pp. 192-205.

Vest J.P., "The Wire", "Deadwood", "Homicide", and "NYPD Blue": Violence is Power, Santa Barbara 2010.

Vint S., The Wire, Detroit 2013.

Williams L., On "The Wire", Durham, NC 2014.

"The Wire" and America's Dark Corners: Critical Essays, eds. A. Keeble, I. Stacy, Jefferson, NC 2015.

"The Wire": Urban Decay and American Television, ed. T. Potter, New York, NY 2009.

$$
* * *
$$

Dawid Junke, Ph.D. - Assistant Professor at the Cultural Studies Institute, University of Wrocław. A scholar of popular culture, he is fascinated with TV shows, films and narratives. His research interests revolve around the cultural aspects of a television show's production and reception. Author of the book Transcendencja i sekularyzacja. Motywy religijne we wspótczesnych amerykańskich serialach telewizyjnych (Transcendence and Secularization. Religious Motifs in Contemporary American Television Shows). Fulbright Slavic Award Nominee.

dawid.junke@uwr.edu.pl

Dawid Junke - doktor nauk humanistycznych, adiunkt w Instytucie Kulturoznawstwa Uniwersytetu Wrocławskiego. Badacz kultury popularnej, zafascynowany serialami telewizyjnymi, filmami i narracjami w innych mediach. Jego zainteresowania badawcze koncentrują się wokół kulturowych aspektów produkcji i recepcji seriali telewizyjnych. Autor monografii Transcendencja i sekularyzacja. Motywy religijne we wspótczesnych amerykańskich serialach telewizyjnych. Nominowany do nagrody Fulbright Slavic Award (planowany wyjazd na stypendium w 2021 roku). 